\title{
Freshwater production and solar disinfection of water released from the air-conditioning cooling system: an experimental investigation
}

\author{
Iessa Sabbe Moosa ${ }^{1, *}$, Laila Masoud Rashid Al-Iessi ${ }^{2}$, and Hussein A. Kazem ${ }^{3}$ \\ ${ }^{1}$ Research cooperator with Public Authority for Water, Al-Buraimi Province, P.C. 512, Oman \\ ${ }^{2}$ Public Authority for Water, Al-Buraimi Province, P.C. 512, Oman \\ ${ }^{3}$ Faculty of Engineering, Sohar University, Sohar, P.C. 311, Oman
}

Received: 11 March 2020 / Accepted: 27 April 2020

\begin{abstract}
Providing drinkable water for people is one of the crux duties of any government worldwide. As long, Oman classified among countries that suffer from a shortage of water resources, therefore finding any new sources of water is considered as very substantial work. In present work, a research was carried out on a massive quantity of water that is released out from cooling air-conditioning system in humid zones in Oman as byproduct water. The results showed that the average quantity of water gained from one AC in chosen cities was about $2 \mathrm{~L} / \mathrm{h}, 1.9 \mathrm{~L} / \mathrm{h}$, and $1.7 \mathrm{~L} / \mathrm{h}$ in Muscat, Sohar, and Al-Buraimi respectively. The results exposed that the water was almost distilled water with a $\mathrm{pH}$ of about 7 . The electrical conductivity was very low, within the range of $45 \mu \mathrm{S} / \mathrm{cm}$ and less. The turbidity of the tested water was low as well, in the range of about 0.6 NTU. Additionally, it was found that solar disinfection technique was very effective to inactivate the existing bacteria in the examined water. A temperature of about $43^{\circ} \mathrm{C}$ can be reached after solar irradiation for $2 \mathrm{~h}$ with transparent bottles. While, a temperature of around $84^{\circ} \mathrm{C}$ was achieved on a sunny day after $6 \mathrm{~h}$ of irradiation time. The significant result of the solar disinfection was that the complete inactivation of bacteria could be achieved with an irradiation period of $2-4 \mathrm{~h}$, depending on the number of bacteria per unit volume and the weather state. Moreover, some of the gained water was converted into drinking water after adding some required elements, filtration and disinfection by solar energy. Also, it is strongly recommended to use the released drainwater from cooling air-conditioning systems in the electrolysis unit cells for hydrogen gas production in conjugation with solar energy.
\end{abstract}

\section{Introduction}

Water-security is a strategic aspiration of life around the world, especially drinking water. Providing high-quality drinking water is essential from a national and humanitarian point of view for any country. In reality, drinking water production needs primary sources of low salinity and germs, where it can be treated easily with a low-cost. Besides that, there are interrelated factors to augment water-security, such as water usage rationalization, community traditions and education, and people's awareness. The Sultanate of Oman is among countries that suffer from lack of water resources, where it does not have rivers, and is classified as a low rainfall country. Most of its natural water resources are groundwater and rainwater stored by

\footnotetext{
* e-mail: dr.iessa89@gmail.com
}

dams in rainy places. It is a growing issue related with the increase of population. Significant information has been reported about groundwater and its management and resources of water in Oman [1,2]. General analysis and very vital data have been reported by Talal et al. about water availability and its management in Oman, using Geographical Information Systems (GIS) [3].

Drinking water can be produced by direct treatment of rivers water as most of them are low salinity, germs, and bacteria, depending on the environmental protection rules followed by each country to avoid contamination. This method is adopted in countries that have rivers such as European countries, Iraq, Syria, Egypt, etc. Nevertheless, countries with no rivers rely on some other resources to supply drinking water, such as groundwater, water desalination in several ways. Examples of the last one are reverse osmosis, distillation of pond water and seawater by solar energy [4-10], and evaporation and condensation 
routes by using conventional fuels. Also, fog harvesting was considered by using mesh net as another way of collecting fresh water in regions of high humidity. Oman is the first country in the region, which started to use this technique in Salalah in the south part of the country to augment its water resources [11]. The author of the reference [11] also stated that the water resources of Oman are classified as follows: groundwater $83 \%$, surface water $5 \%$, treated wastewater $2 \%$, and desalination $10 \%$.

Another way of providing drinking water, which may be adopted is to collect released drain-water resulting from air-conditioning cooling units as a byproduct. This water was found to be almost distilled water with low turbidity, and its value of $\mathrm{pH}$ is about 6.9. In 2018, this subject was studied practically with a brief review of water status in Oman by Moosa et al. [12]. They concluded that the byproduct water from any air-conditioning cooling system could be easily converted into drinking water by using the general procedure of preparing this kind of water. In countries with high level of humidity and using cooling systems, the amount of collected water will be vast and can be used in different ways for domestic purposes, and probably transformed into drinking water. This study emphasizes the need to exploit drain byproduct water from any air-conditioning cooling system in several ways, such as distilled water production, drinking water after disinfection process, hydrogen gas production and water for dripping irrigation technique in modern agriculture. Hence, it is a big loss to let it go into the sewage system or to be wasted water for nothing. This ready-in-hand source of water, probably contributes to solve the problem of water deficiency, especially the drinking water in several regions around the world.

The aims of this paper are to investigate some chemical and physical parameters, the uses of drain-water collected from air-conditioning cooling systems, and try to convert it into drinking water. Meanwhile, it is an attempt to prove that this kind of water may be used as a distilled water for different purposes. It also explores the possibility of using solar energy for water disinfection purpose.

\section{Water disinfection}

Disinfection of drinking water is an essential process to produce water ready for human use following all necessary steps of production. There are several ways to disinfect the water to convert it into drinking water; these are.

\subsection{Ultra Violet-B (UV-B) radiation}

Using this type of radiation is efficient for very low turbidity to avoid diffusion of radiation. The approximate wavelength of this radiation is within the range of 290$320 \mathrm{~nm}$, which is ready to damage the DNA of any viruses and bacteria in the used water [13]. Wei from Colorado State University has reported distinct classification and function for all types of UV radiations (UV-A, UV-B, and UV-C) according to their wavelengths, as well as their influence on biological organisms [14]. He stated that the ozone layer absorbs UV-C at the top of the Earth's
Table 1. Solar spectrum distribution [14].

\begin{tabular}{lll}
\hline Spectral region & Wavelength & \% of Total energy \\
\hline Infrared & $>700 \mathrm{~nm}$ & 49.4 \\
Visible & $700-400 \mathrm{~nm}$ & 42.3 \\
UV-A & $400-320 \mathrm{~nm}$ & 6.3 \\
UV-B & $320-290 \mathrm{~nm}$ & 1.5 \\
UV-C & $<290 \mathrm{~nm}$ & 0.5 \\
\hline
\end{tabular}

atmosphere, a part of the UV-B can reach the Earth's surface and devastate biological organisms, while the UV-A with no effect on biological organisms when it reaches the surface of the Earth.

In 2019, the efficiency of the solar reactor technique to inactivate bacteria in water has been studied by Ayoub et al. [15]. Their remarkable work focused on using of the UV-A and UV-B bands that already exist in the solar spectrum for solar disinfection. They showed that the inactivation efficiency of the solar reactor depends on the transparency of the used container, exposure time, and on the other materials' that supported the reactor, such as aluminum foil reflector, insulator, half coating silver mirror, black paint coating, and $\mathrm{TiO}_{3}$ coating layer. They also reported that $4 \mathrm{~h}$ of exposure time is enough to kill $99.9 \%$ of existing bacteria in the tested water. Solar spectrum characteristics are given in Table 1.

\subsection{Chlorination}

Adding some chlorine element within the standard limit of any country. This method is quite common for large-scale mass production route with low-cost and residual to avoid future recontamination after pumping the drinking water in the public network for domestic use [14]. The limit of adding this element to drinking water for disinfection purpose is in the range of $0.2-1.0 \mathrm{mg} / \mathrm{L} \mathrm{[16]}$.

\subsection{Solar disinfection}

Solar radiation can be easily applied for water disinfection from germs, protozoa, viruses, and bacteria, because of existing the UV and infrared radiations in the Sun spectrum, besides heating effect. This process is appropriate at a householder's level to avoid waterborne diseases as much as possible by exposing filled transparent bottle of water to sunlight for about 6 hours after filtration procedure to remove solid and suspended organic materials [17]. More detailed information has been investigated about this featured topic in the following references [18-20]. Solar disinfection is the easiest way in places that have high and reasonable solar intensity during the most daytime a year. According to the World Health Organization (WHO), solar disinfection is the easiest, and practical way to disinfect the water that subjected to be drinking water [21]. It is very proper for Omani rural areas because Oman is receiving high solar radiation during all days of the year [22]. It is recommended to be used when other methods of disinfection are not 
Table 2. Shows instruments and used methods for chemical, physical, and bacteriology tests.

\begin{tabular}{llll}
\hline Test parameter & Equipment or stuff & Standard method & Uncertainty \\
\hline $\begin{array}{l}\text { Bacteriological } \\
\text { (Coliform \& E. coli) }\end{array}$ & Colilert method & APHA 9222B (Colifor m) & Color change \\
pH, electrical conductivity (EC), & Thermo pH, EC Meters & EPA150.1 \& EPA, 180.1 & $\mathrm{pH} \pm 0.02$ \\
turbidity, temperature & & \& Std Method & EC $\pm 20 \%$ \\
$\begin{array}{l}\text { Chloride, alkalinity, total } \\
\text { hardness \& calcium hardness }\end{array}$ & Titration by digital burette & APHA 2320B & $\pm 5 \%$ \\
Sodium \& Fluoride $_{\mathrm{SO}_{4}{ }^{2-} \& \mathrm{PO}_{4}{ }^{2-} \& \mathrm{NO}_{3}{ }^{-}}$ & Ion Selective, Electrode. (ISE) & Direct measurement & $\pm 5 \%$ \\
$\mathrm{Relative} \mathrm{humidity}_{\text {Solar intensity }}$ & UV Spectrophotometer DR6000 & EPA method 300.0 & $\pm 5 \%$ \\
& Humidity meter, HTC-1 & Direct measurement, RH\% & $\pm 5 \%$ \\
Temp. measurement & Digital light intensity meter, & Direct measurement & $\pm 3 \%$ \\
\hline & Type MT-4617 & & $\pm 0.1^{\circ} \mathrm{C}$ \\
\hline
\end{tabular}

available. Generally, It is very suitable for rural areas due to the synergy between the UV band and thermal effect of the infrared band in the solar spectrum.

\subsection{Water heating}

Heating to about $63^{\circ} \mathrm{C}$ and more up to the boiling point of the water is probably employed for disinfection [18]. This route depends on energy sources available and their prices.

\subsection{Ozonation}

In this way, the ozone gas $\left(\mathrm{O}_{3}\right)$ uses to disinfect the water ready to be drinking water. The cost of this method is higher than the chlorination route because of the high cost of ozone gas preparation. This method is appropriate for small-scale drinking water production. Ozone is very effective gas in the disinfection process because of its high oxidation effectiveness [23]. Significant details have been mentioned about this method of disinfection in the preceding reference.

\section{Experimental facilities}

The experimental work was carried out by employing the following facilities and steps:

- Split AC units with a power of $2000 \mathrm{~W}$.

- A removable water filter that can be fixed in a plastic container designed for water filtration purpose, German Made type TIP.

- Some plastic and Pyrex Glassware containers for as received water collocation, chemical analysis, and biological analysis.

- Homemade isolated wooden box with double glazing front side for water solar disinfection purpose.

- Digital thermometer.

- Digital humidity meter for Relative Humidity (RH\%) measurement, Digital light intensity meter type MT-4617 to measure solar intensity.

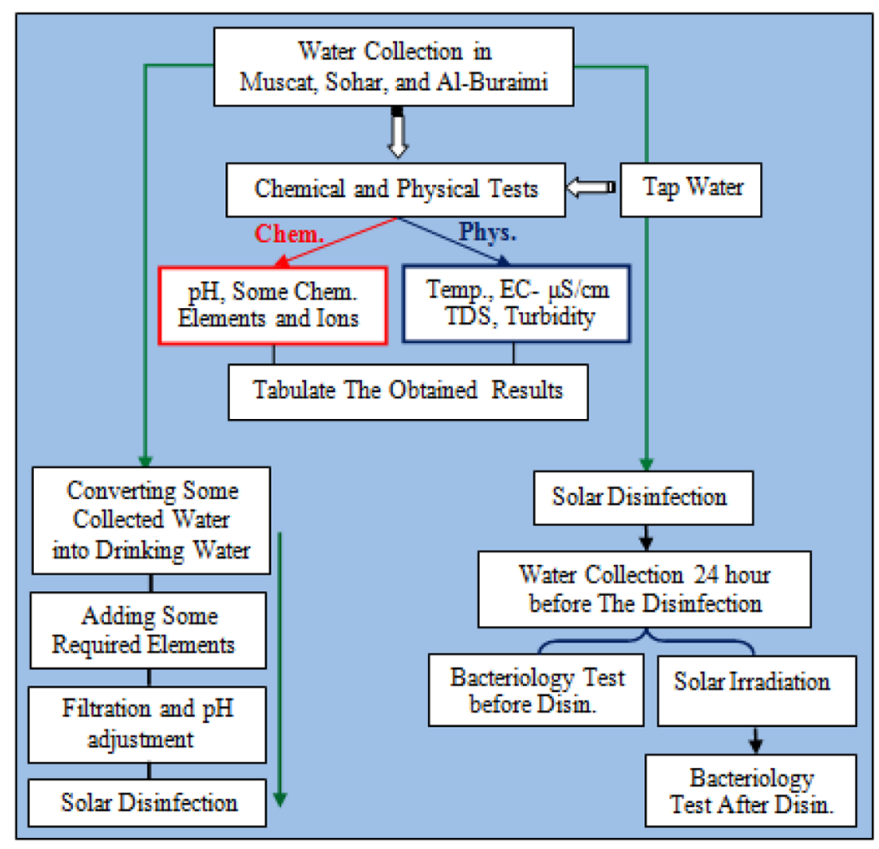

Fig. 1. Illiterates the flowchart of the research work.

- Autoclave type STURDY- SA-300 VFA, CE - 0434 for sterilizing purpose.

- Incubator type SHIN SAENG, south KOREN made.

All chemical, physical, and bacteriology tests were carried out in the labs. of Public Authority for Water, Al-Buraimi Province, Oman. Table 2 includes the equipment, methods, that were used to carry out the tests related to the research work, together with the uncertainty \% values. Figure 1 shows the flowchart of the practical work.

Figures 2 and 3 show the used double glazing wooden box, solar intensity meter, humidity meter, and digital thermometer. 


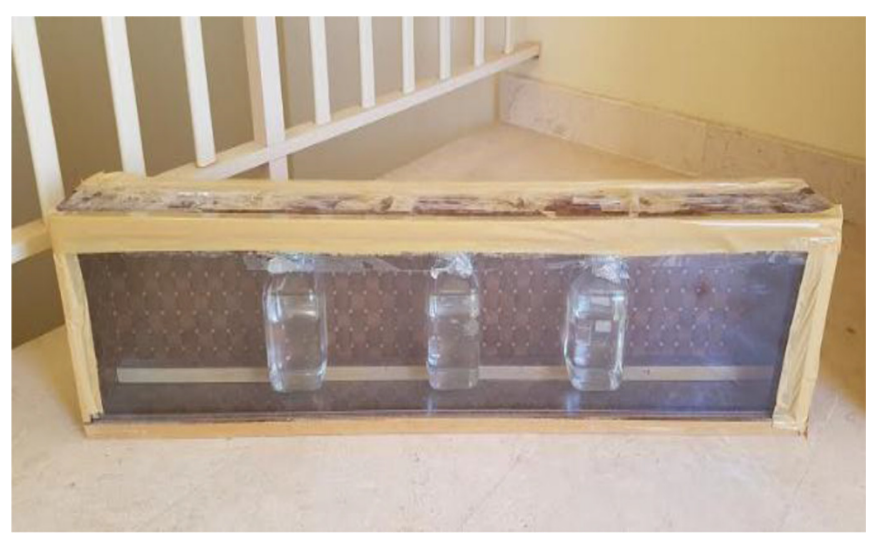

Fig. 2. Double glazing box for solar disinfection.

\section{Experimental procedure}

At the beginning, the calibration process for used instruments and devices that mentioned in Table 2 was carried out according to their provided instruction manuals. As for the Autoclave and the incubator, they are not analytical instruments, so there is no need for calibration. The Autoclave is used to sterilize the used bottles prior for bacteriology tests only, and there are provided strips to know if the bottles sterilized or not. For the Incubator, it always calibrates each year by approved calibration labs. and giving a certificate for it, so there is no precision / uncertainty (the accepted differences are $\pm 0.5^{\circ} \mathrm{C}$ ). Additionally, during chemical and physical tests, the temperature was monitored well as it is very affected factor on the uncertainty of the results, especially the $\mathrm{pH}$ values and the electrical conductivity. Measurements temperature was almost in the range of room temperature $\left(\sim 20^{\circ} \mathrm{C}\right)$.

\subsection{Water collection}

Drain-water from ACs was collected in three cities, namely Muscat, Sohar, and Al-Buraimi on different dates. The names of the cities, dates, $\mathrm{RH} \%$, and the rate water collection are given in Table 3 . The collected water of Muscat was about $31 \mathrm{~L}$ within a period of approximately $15 \mathrm{~h}$. In Sohar, the gained water was around $15 \mathrm{~L}$ at a period of $8 \mathrm{~h}$. As for Al-Buraimi city, which is not a coastal city, the quantity was about $7 \mathrm{~L}$ within a period of $4 \mathrm{~h}$.

\subsection{Chemical and physical analysis}

Three replicate samples were taken from ACs drain-water in Muscat, Sohar, and Al-Buraimi for chemical and physical tests. In addition, chemical and physical tests were also done for three replicate samples of drinking tap water in Al-Buraimi for comparison purpose. The obtained results together with the Omani standard of drinking water are reported in Table 4.

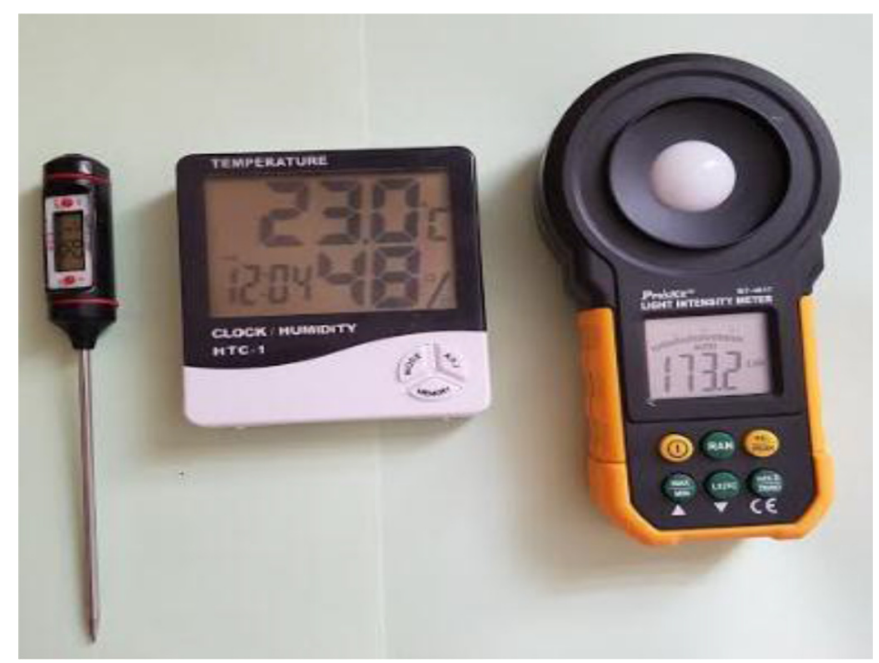

Fig. 3. To the left: digital thermometer, in the middle: humidity meter, to the right: solar intensity meter.

Table 3. Includes the details of collected drain-water from the used ACs.

\begin{tabular}{llll}
\hline City & Date & $\approx \mathrm{RH} \%$ & $\begin{array}{l}\text { Approximate } \\
\text { water collection } \\
\text { rate L/h }\end{array}$ \\
\hline Muscat & $02 / 11 / 2019$ & $63 \%$ & 2 \\
Sohar & $20 / 11 / 2019$ & $61 \%$ & 1.9 \\
AL-Buraimi & $10 / 12 / 2019$ & $57 \%$ & 1.7 \\
\hline
\end{tabular}

Place of collection: Muscat: $\approx 1.5 \mathrm{~km}$ from the costal line; Sohar: $\approx 1.85 \mathrm{~km}$ from the coastal line; Al-Buraimi: city center, is not coastal city.

\subsection{Bacteriology test and solar disinfection}

For bacteriology tests and disinfection process by solar energy, six samples of $0.5 \mathrm{~L}$ and $0.2 \mathrm{~L}$ capacities Pyrex glass bottles were used for water collection in the three selected Provinces. These bottles were sterilized in advance using the Autoclave system to make them ready for water collection for bacteriology tests. The sterilizing condition was as follows: heating up to about $121^{\circ} \mathrm{C}$ with a pressure of about $14 \mathrm{psi}$ for $15 \mathrm{~min}$. The samples were collected 24 hours before the test time, according to the adopted procedure. Three of these samples were tested as normal after an incubation period of about $18 \mathrm{~h}$ at $35^{\circ} \mathrm{C}$ in the provided incubator employing the Colilert Method (APHA 9222B [(Colifor, m) \& APHA 9222D, (E. coli)]. The other three samples were irradiated by sunlight for $2 \mathrm{~h}, 4 \mathrm{~h}$, and $6 \mathrm{~h}$ for disinfection by using the provided double glazing wooden box, after that, the samples were also subjected to the same procedure above for bacteriology test. Also, another ten samples were collected in Al-Buraimi, three of them were tested before solar disinfection, while the other 7 samples of $0.2 \mathrm{~L}$ capacity were irradiated for $1 \mathrm{~h}, 2 \mathrm{~h}, 2.5 \mathrm{~h}$, $3 \mathrm{~h}, 4 \mathrm{~h}, 5 \mathrm{~h}$, and $6 \mathrm{~h}$. The aim of this attempt is to determine the most appropriate time and temperature to kill all 
Table 4. Shows the mean values of Muscat, Sohar, Al-Buraimi, and tap water tested parameters of three replicates samples, together with the Omani standard for comparison purpose.

\begin{tabular}{|c|c|c|c|c|c|c|}
\hline \multirow[t]{2}{*}{ Parameters } & \multicolumn{3}{|c|}{$\begin{array}{l}\text { Results: mean value of } 3 \text { samples } \\
\text { of collecting drain-water }\end{array}$} & \multicolumn{3}{|c|}{ Tap Water, Omanian St. 8/2012 } \\
\hline & Muscat & Sohar & Al-Buraimi & Para. & Quality level & Max. \\
\hline Temperature: $\left({ }^{\circ} \mathrm{C}\right)$ & 20.7 & 22 & 19.1 & 21.2 & $20-25$ & - \\
\hline Turbidity*: (NTU) Nephok True Unit & 0.57 & 0.94 & 2.1 & 0.4 & 1 & 5 \\
\hline $\mathrm{pH}^{*}$ & 7.01 & 6.9 & 7.01 & 8.44 & $6.5-8.5$ & 9.0 \\
\hline Electrical Conductivity: EC $(\mu \mathrm{S} / \mathrm{cm})$ & 25.29 & 40.44 & 45.68 & 312.39 & - & - \\
\hline TDS $^{*}$ (Total Dissolved Solids) (mg/L) & 16.44 & 25.29 & 29.69 & 203 & $120-600$ & 1000 \\
\hline Chloride $\mathrm{Cl}^{-}(\mathrm{mg} / \mathrm{L})^{*}$ & 6.17 & 3.7 & 4.68 & 153.68 & $<250$ & 600 \\
\hline Phenolphthalein. Alkalinity (mg/L) & 0.0 & 0.0 & 0.0 & 2.8 & - & - \\
\hline Total alkalinity $(\mathrm{mg} / \mathrm{L})^{*}$ & 12.6 & 17 & 20.33 & 71 & - & - \\
\hline Calcium hardness $(\mathrm{mg} / \mathrm{L})$ & 2.8 & 2.46 & 7.53 & 48 & - & - \\
\hline Total Hardness (mg/L) & 4.13 & 3.33 & 7.8 & 86.8 & $<200$ & 500 \\
\hline $\mathrm{NO}_{3}{ }^{-}(\mathrm{mg} / \mathrm{L})^{*}$ & 1.03 & 0.39 & 1.42 & 0.9 & - & 50 \\
\hline $\mathrm{PO}_{4}{ }^{2-}(\mathrm{mg} / \mathrm{L})$ & $<0.06$ & 0.063 & $<0.06$ & 0.06 & - & - \\
\hline $\mathrm{SO}_{4}{ }^{2-}(\mathrm{mg} / \mathrm{L})^{*}$ & 2.47 & 1.73 & 5.82 & 8.83 & $<250$ & 400 \\
\hline $\mathrm{Na}^{+}(\mathrm{mg} / \mathrm{L})^{*}$ & $<0.02$ & 1.7 & 0.38 & 0.9 & $<200$ & 400 \\
\hline Fluoride $\mathrm{F}^{+}(\mathrm{mg} / \mathrm{L})^{*}$ & 0.058 & 0.03 & 0.03 & 0.7 & $\begin{array}{l}0.6-0.8 \text { Desalinated } \\
\text { water }\end{array}$ & 1.5 \\
\hline
\end{tabular}

* Adopted Values, Omani Standards.

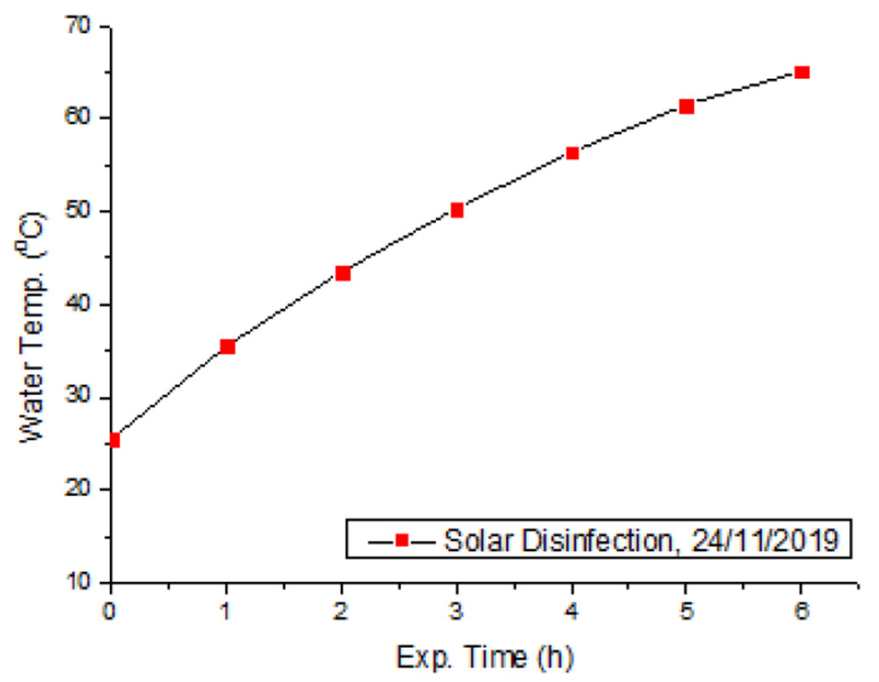

Fig. 4. Curve of water temp. vs. exp. time during water disinfection of Sohar, starting time: 8:00 am.

existing bacteria in the tested water. During the irradiation process, the temperature as a function of time was measured using the digital thermometer. Meanwhile, the digital light intensity meter was used to follow the solar intensity as a function of time during solar irradiation. The obtained results were graphed, as depicted in Figures 4-8.

The bacteriology test results before and after solar irradiation for the three cities are summarized in Tables 5-9.

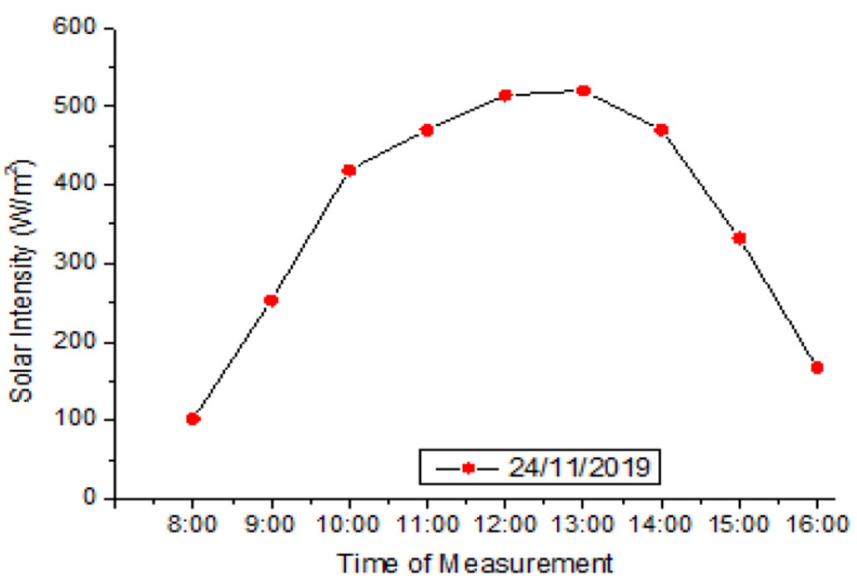

Fig. 5. Curve of solar intensity vs. exp. time, sunny day, Al-Buraimi, winter season, starting time: 8:00 am.

During the bacteriology tests, some cases were photographed before and after solar irradiation to follow the results of the bacterial analysis. Figure 9 reveals the result of 3 samples subjected to bacteriology tests before and after solar irradiation for $2 \mathrm{~h}, 4 \mathrm{~h}$, and $6 \mathrm{~h}$ using the double glazing wooden box. Also, the results of the bacteriology tests before and after $1 \mathrm{~h}, 2 \mathrm{~h}, 2.5 \mathrm{~h}, 3 \mathrm{~h}, 4 \mathrm{~h}, 5 \mathrm{~h}$, and $6 \mathrm{~h}$ solar irradiation are shown in Figures 10 and 11.

\subsection{Freshwater production}

An attempt was made to convert some of the water gained from the used cooling system into drinking water according 


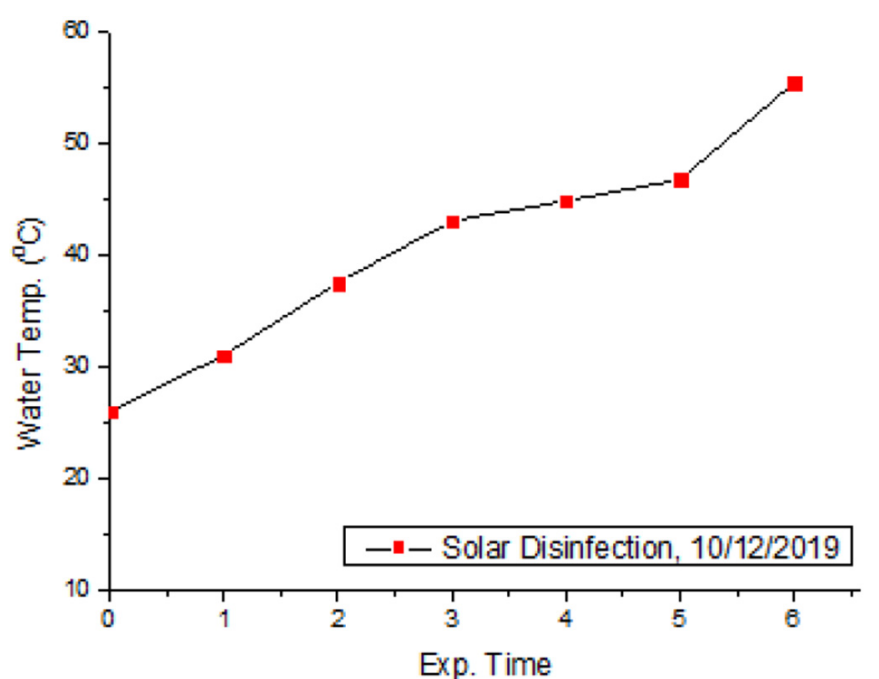

Fig. 6. Curve of water temp. vs. exp. time during water disinfection of Al-Buraimi, $\sim 50 \%$ cloudy weather, starting time: 8:00 am.

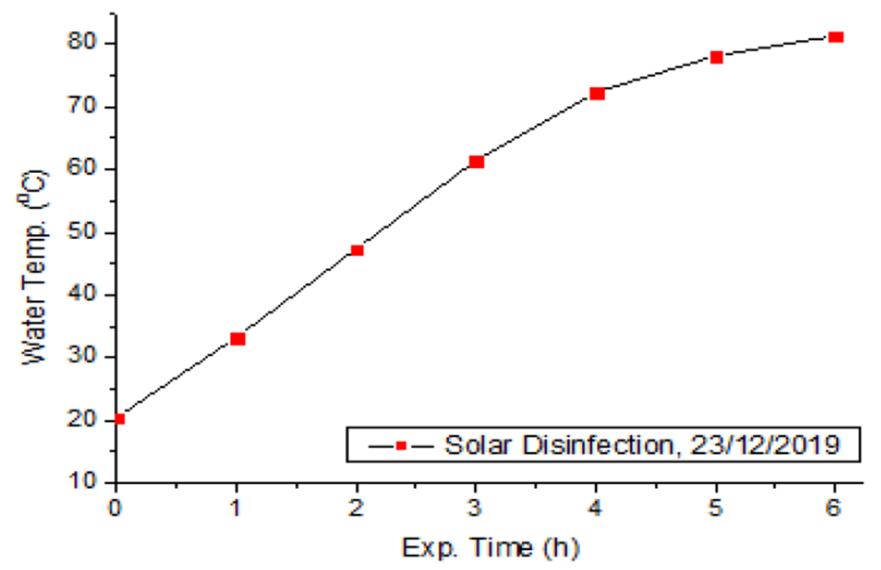

Fig. 7. Curve of water temp. vs. exp. time during water disinfection of Al-Buraimi, sunny day, starting time: 8:00 am.

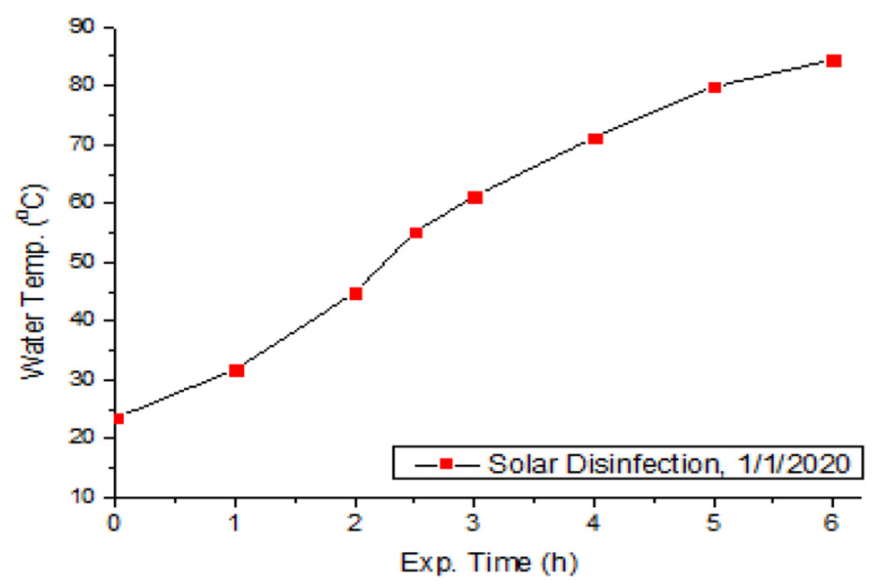

Fig. 8. Curve of water temp. vs. exp. time during water disinfection of Al-Buraimi, sunny day, starting time: 8:00 am.
Table 5. Bacteriology results for Muscat, 24/11/2019.

\begin{tabular}{|c|c|c|c|}
\hline \multicolumn{4}{|c|}{ Bacteriology results before sunlight irradiation, Musc } \\
\hline $\mathrm{MPN} / 100 \mathrm{~mL}$ & Sample-1 & Sample-2 & Sample-3 \\
\hline Coliform & $<1$ & 8.7 & 15 \\
\hline E. coli & $<1$ & 8.7 & 12.4 \\
\hline \multicolumn{4}{|c|}{ Bacteriology results after sunlight irradiation } \\
\hline$\overline{\mathrm{MPN}} / 100 \mathrm{~mL}$ & $2 \mathrm{~h}, 43^{\circ} \mathrm{C}$ & $4 \mathrm{~h}, 56^{\circ} \mathrm{C}$ & $6 \mathrm{~h}, 65^{\circ} \mathrm{C}$ \\
\hline Coliform & $<1$ & $<1$ & $<1$ \\
\hline E. coli & $<1$ & $<1$ & $<1$ \\
\hline
\end{tabular}

Note: $<1$ means almost 0, no active bacteria.

Table 6. Bacteriology results for Sohar, 24/11/2019.

\begin{tabular}{|c|c|c|c|}
\hline \multicolumn{4}{|c|}{ Bacteriology results before sunlight irradiation, Sohar } \\
\hline$\underline{\mathrm{MPN} / 100 \mathrm{~mL}}$ & Sample-1 & Sample-2 & Sample-3 \\
\hline Coliform & $<1$ & 2 & $<1$ \\
\hline E. coli & $<1$ & $<1$ & $<1$ \\
\hline \multicolumn{4}{|c|}{ Bacteriology results after sunlight irradiation } \\
\hline $\mathrm{MPN} / 100 \mathrm{~mL}$ & $2 \mathrm{~h}, 43^{\circ} \mathrm{C}$ & $4 \mathrm{~h}, 56^{\circ} \mathrm{C}$ & $6 \mathrm{~h}, 65^{\circ} \mathrm{C}$ \\
\hline Coliform & $<1$ & $<1$ & $<1$ \\
\hline E. coli & $<1$ & $<1$ & $<1$ \\
\hline
\end{tabular}

Table 7. Bacteriology results for Al-Buraimi, 10/12/ 2019.

\begin{tabular}{llll}
\hline \multicolumn{4}{c}{$\begin{array}{c}\text { Bacteriology results before sunlight irradiation, } \\
\text { Al-Buraimi }\end{array}$} \\
\hline MPN/100 mL & Sample-1 & Sample-2 & Sample-3 \\
\hline Coliform & $>200.5$ & $>200.5$ & $>200.5$ \\
E. coli & 3 & 4 & 4 \\
\hline \multicolumn{4}{c}{ Bacteriology results after sunlight irradiation } \\
\hline MPN/100 mL & 6 h continuous, $55.3{ }^{\circ} \mathrm{C}, ~$ & $\sim 50 \%$ cloudy \\
Coliform & $<1$ & $<1$ & $<1$ \\
E. coli & $<1$ & $<1$ & $<1$ \\
\hline
\end{tabular}

Note: High concentration of bacteria was found in shallow collected water from AC unit, while the concentration was very low when the water is collected directly from the used AC.

to the following procedure:

- Taking a certain amount of the collected water to convert it into drinking water, about $1 \mathrm{~L}$.

- Adding some required elements according to the Omani water preparation standard route.

- Filtrating the produced water to control the turbidity value to be within the standard limit of Omani drinking water, and adjust the value of its $\mathrm{pH}$ if needed.

- Disinfecting the water by solar irradiation for about $4 \mathrm{~h}$ on a sunny day. 
Table 8. Bacteriology results for Al-Buraimi, 23/12/ 2019.

Bacteriology results before sunlight irradiation, Al-Buraimi

\begin{tabular}{llll}
\hline MPN/100 mL & Sample-1 & Sample-2 & Sample-3 \\
\hline Coliform & $>200.5$ & $>200.5$ & $>200.5$ \\
E. coli & 4.2 & 1.0 & 1.0 \\
\hline
\end{tabular}

$\begin{array}{lccc}\text { E. coli } & 4.2 & 1.0 & 1.0 \\ \text { Bacteriology results after sunlight irradiation }\end{array}$

\begin{tabular}{llll}
\hline $\mathrm{MPN} / 100 \mathrm{~mL}$ & $2 \mathrm{~h}, 47^{\circ} \mathrm{C}$ & $4 \mathrm{~h}, 72{ }^{\circ} \mathrm{C}$ & $6 \mathrm{~h}, 81^{\circ} \mathrm{C}$ \\
Coliform & $>200.5$ & $<1$ & $<1$ \\
E. coli & $<1$ & $<1$ & $<1$ \\
\hline
\end{tabular}

Table 9. Bacteriology results for Al-Buraimi, 1/1/2020.

Bacteriology results before sunlight irradiation, Al-Buraimi

\begin{tabular}{llll}
\hline MPN/100 mL & Sample-1 & Sample-2 & Sample-3 \\
\hline Coliform & 6.4 & 6.4 & 2 \\
E. coli & $<1$ & $<1$ & $<1$ \\
\hline
\end{tabular}

\begin{tabular}{lllc}
\hline \multicolumn{4}{c}{ Bacteriology results after sunlight irradiation } \\
\hline $\mathrm{MPN} / 100 \mathrm{~mL}$ & Sample-1 & 1h & Samples-2 $\rightarrow 7$ \\
& $32^{\circ} \mathrm{C}$ & $2 \mathrm{~h}, 2.5 \mathrm{~h}, 3 \mathrm{~h}, 4 \mathrm{~h}, 5 \mathrm{~h}, 6 \mathrm{~h}$ \\
& & $45,55,61,71,80,84^{\circ} \mathrm{C}$ \\
Coliform & 2 & $<1$ & $<1$ \\
E. coli & $<1$ & $<1$ & $<1$ \\
\hline
\end{tabular}

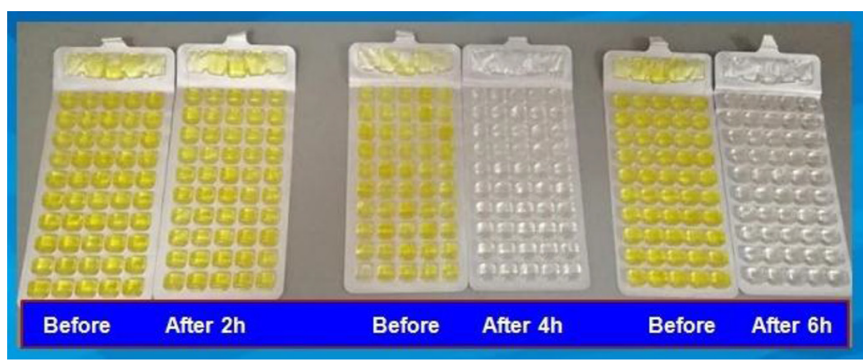

Fig. 9. Bacteriology tests of the collected water of Al-Buraimi, Date: $23 / 12 / 2019$, before and after solar irradiation.

\section{Results and discussion}

First, the values in Table 3 show that the quantity of collected water is proportioned to the $\mathrm{RH} \%$, and this is quite normal result. Therefore, a vast of water can be gained as a byproduct from cooling air-conditioning units in humid places worldwide. It can be easily concluded from Table 4 that the obtained chemical and physical parameters of tested drain-water in the three selected cities are mostly different, except the $\mathrm{pH}$ values of nearly equal, about 7 . These differences are logical because of having different areas of water collection, which certainly

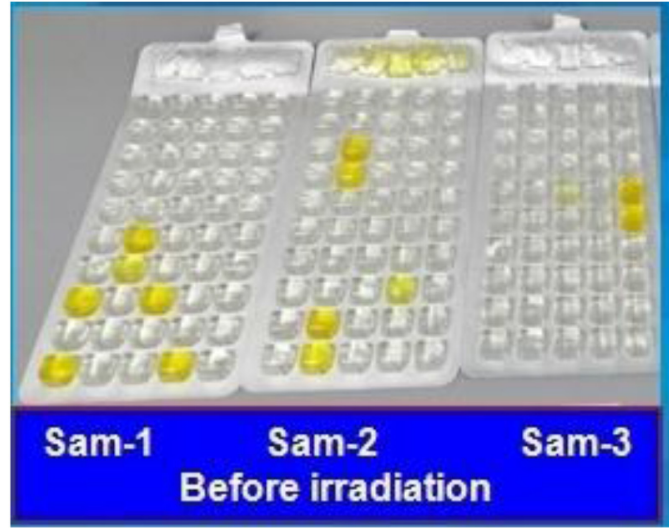

Fig. 10. Bacteriology tests Al-Buraimi water, Date:1/1/2020, before solar irradiation.

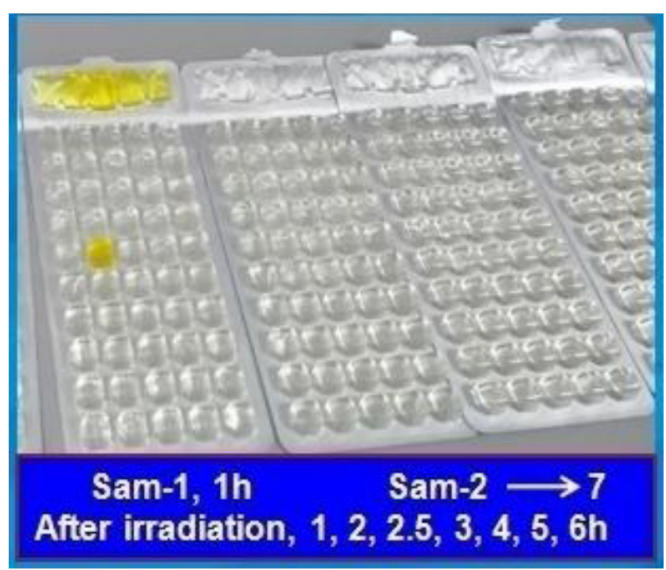

Fig. 11. Bacteriology tests Al-Buraimi water, Date: 1/1/2020, after solar irradiation.

differ in their environmental conditions. This situation inevitably leads to the differences in the physical and chemical properties of the collected water, especially its electrical conductivity and the turbidity. On the other hand, there are very slight differences in the other parameters, which may be due to their very little concentration. In general, the results showed that the ACs drain-water is characterized by low turbidity and very low electrical conductivity and TDS, with a $\mathrm{pH}$ of about 7 , hence it will be almost distilled water after disinfection and filtration processes. The result in Table 4 also showed that drinking tap water is compatible with the standard quality level of Oman.

In conclusion, that the filtered cooling air-conditioning system drain-water can be used as distilled water for several purposes after adjusting its $\mathrm{pH}$, which may decrease after filtration, to make it about 7 by adding some additives, such as sodium hydroxide. Additionally, this gained byproduct water from any air-conditioning cooling system can also be used in water electrolysis cells for hydrogen production, especially in the high humidity regions worldwide. The collected byproduct 
water could look upon as a result of the correlation between electric and solar energy. The solar energy produces water vapor from surface water sources and then the vapor converts into pure water through condensation process in the used AC, which normally runs by electric energy. It is unwise to waste vast quantities of water nationwide to go to the sewage system or to be surface water to evaporate again. Therefore, the released drain-water from any cooling systems should be collected and used as almost free of charge pure byproduct water. Overall, the amount of water collected from any cooling system is considerable in coastal and agricultural areas which are characterized by high relative humidity of up to $80 \%$ and higher.

The obtained results of the bacteriology tests before and after sunlight irradiation in Tables 5-9 show that there are some types of bacteria in the tested water. These bacteria certainly come from the ambient atmosphere when the humid air enters the used cooling airconditioning unit. The results also revealed that the solar disinfection was successful in killing all existing bacteria within $2 \mathrm{~h}$ of irradiation with a temperature of about $43^{\circ} \mathrm{C}$ and above with low quantities of bacteria per unit volume as confirmed in Tables 5 and 6 . The result of Table 7 shows that solar disinfection can be carried out even in cloudy weather when the temperature at the end of $6 \mathrm{~h}$ irradiation continuously reaches about $55^{\circ} \mathrm{C}$, plus the effect of the UV-B ray in the sunlight. This speculation has been confirmed in the result recorded in Table 8 , when all bacteria in the water of Al-Buraimi was killed after $4 \mathrm{~h}$ of irradiation at a temperature of about $72{ }^{\circ} \mathrm{C}$, when the quantity of bacteria per unit volume is high, such as $>200.5 \mathrm{MPN} / 100 \mathrm{~mL}$. Also, the result in this Table reveals that when the temperature of the water reaches about $47^{\circ} \mathrm{C}$ after $2 \mathrm{~h}$, still some active bacteria is there. Based on these results, it seems that when the quantity of bacteria per unit volume is high, the water temperature must reach a value of about $60^{\circ} \mathrm{C}$, beside the effect of the UV-B radiation to kill all bacteria in the tested water. Also, the results in Tables 7 and 8 showed that high concentration of bacteria was found in collected water from AC unit in Al-Buraimi (>200.5 MPN/ $100 \mathrm{~mL}$ ), since it's been accumulated for long time. While the concentration was very low when the tested water collected directly from the used AC as confirmed in Table 9, the bacteria concentration mean value in this table is about $5 \mathrm{MPN} / 100 \mathrm{~mL}$. It seems the reason of increasing the bacteria concentration in the accumulated water may be due to bacteria breeding cycle in an appropriate conditions, This case needs more study.

Based on the previous results, the solar disinfection technique is recommended to be used in countries that enjoy with high and reasonable solar intensity. Using this route of disinfection will save the cost of the other ways that must be used to disinfect the drinking water, and it is the easiest method.

From Figure 4 of Sohar irradiation, the temperatures of $2 \mathrm{~h}, 4 \mathrm{~h}$, and $6 \mathrm{~h}$ of exposure times are $43.5^{\circ} \mathrm{C}, 56.4^{\circ} \mathrm{C}$, and $65.1^{\circ} \mathrm{C}$ respectively. The action of solar disinfection is due to two reasons; these are:
- Existing of the narrow band intensity of the UV-B that already exists in the solar radiation spectrum which reaches the Earth's surface.

- Existing of broadband of infrared radiation in the solar radiation spectrum as seen in Table 1, that causes heating which probably disinfects the water if the temperature exceeds $50{ }^{\circ} \mathrm{C}$ [24]. These two reasons are working together to disinfect contaminated water.

Figure 5 shows the curve of the solar intensity $\left(\mathrm{W} / \mathrm{m}^{2}\right)$ with exposure time (h) according to the mentioned date, from which it can be seen that the highest solar intensity is about $520 \mathrm{~W} / \mathrm{m}^{2}$ at noontime. The curve represents the ideal solar radiation intensity profile as a function of time for a sunny day in winter season. Also, from Figure 6 , it can be seen that the temperature was around $55^{\circ} \mathrm{C}$ after $6 \mathrm{~h}$ of exposure time in $\sim 50 \%$ cloudy weather. It seems that this condition was enough to disinfect the used water according to the bacteriology test results reported in Table 7. From Figure 8 , the water temperatures were $47^{\circ} \mathrm{C}$, $72^{\circ} \mathrm{C}, 81^{\circ} \mathrm{C}$ during irradiation exposure times of $2 \mathrm{~h}, 4 \mathrm{~h}, 6 \mathrm{~h}$ respectively on $23 / 12 / 2019$. The bacteriology test result of this date showed that the disinfection of the used water was done after $4 \mathrm{~h}$ of solar irradiation as indicated by color change from yellow to transparent, as shown in Figure 9. Figure 7 reveals the measurement correlated with disinfection process that carried out on $1 / 1 / 2020$, from which it can be concluded that the temperatures after irradiation exposure times $1 \mathrm{~h}, 2 \mathrm{~h}, 2.5 \mathrm{~h}, 3 \mathrm{~h}, 4 \mathrm{~h}$, $5 \mathrm{~h}$, and $6 \mathrm{~h}$ were $32^{\circ} \mathrm{C}, 45^{\circ} \mathrm{C}, 55^{\circ} \mathrm{C}, 61^{\circ} \mathrm{C}, 71^{\circ} \mathrm{C}, 80^{\circ} \mathrm{C}$ and $84^{\circ} \mathrm{C}$ respectively. The bacteriology result of the date above exposed that full disinfection was completed within $2 \mathrm{~h}$ and more as shown in Figures 10 and 11 because the quantity of bacteria per unit volume is low, as shown in Table 9 .

In the listed literatures about solar disinfection in this article stated that they used direct irradiation route for solar disinfection. Generally, the irradiation time was a bit high, within the range of $4 \mathrm{~h}-6 \mathrm{~h}[15,17]$. While the effective disinfection exposure time was found to be almost half of this range of time, when the wooden double glazing box was used in the current research work, about $2 \mathrm{~h}-3 \mathrm{~h}$ during sunny and partially cloudy days. The reasons of reducing the effective irradiation time are that the double glazing box acts as water heating system, therefore the temperature of the water will increase sharply, in addition to the effect of the UV radiation in the solar spectrum that reaches the surface of the Earth.

\section{General recommendations}

In the end, the following general recommendations can be made with regard to the byproduct drain-water released from the air-conditioning cooling systems along with the solar disinfection:

- The byproduct water can be considered as a source of primary clean water for different purpose uses.

- Availability of water is the most important national issue from life sustainability point of view, so that finding any new source of water must be maintained and developed. 


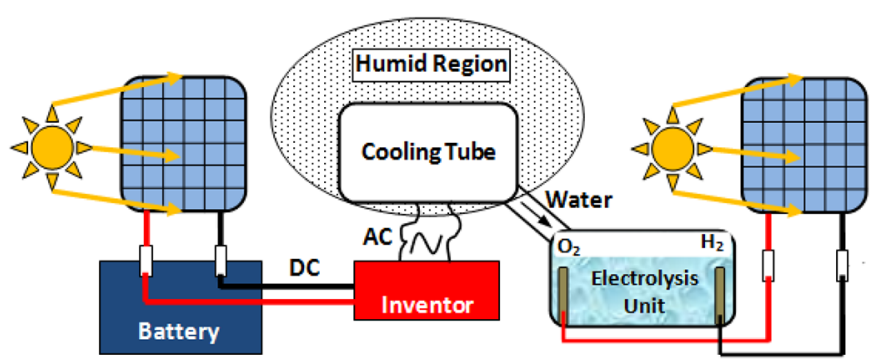

Fig. 12. Schematic diagram of hydrogen production in conjugation of solar energy and gained water from cooling airconditioning system.

- The drain-water can be used in electrolysis unit cells to generate hydrogen gas as a promising renewable fuel. Mainly if the production process is conjugated with some renewable energy sources such as wind and solar energy [25]. Economically, it is rational to use this byproduct water for hydrogen production by electrolysis technique as schematically shown in Figure 12, which already leads to reduce the production cost.

- The gained byproduct water can be used as a drip irrigation technique for modern agriculture to produce a different type of plants, especially in the soil where salinity is slightly more than the natural state of arable soil.

- Solar disinfection is found to be effective, cheap, and easy method.

- Collecting the drain-water from cooling air-conditioning units at the national level probably helps to solve the water scarcity problem.

\section{Conclusions}

The intent of this study is to investigate and give a distinctive importance about the water coming out of the cooling air-conditioning systems as a byproduct in the humid areas. The quantities are large and must be considered at the national level. Also, special attention was given for physical, chemical analysis, and bacteriology tests for several samples of the collected water from the three chosen cities in the Sultanate of Oman. In addition, solar disinfection technique was used to disinfect the collected water with bacteria that already discovered in the tested water. From the obtained findings out, the following points can be concluded:

- The average quantity of drain-water from one AC was about $48 \mathrm{~L} /$ day, the $\mathrm{RH} \%$ was around 65\%. This quantity increases with the increasing of the $\mathrm{RH} \%$.

- The chemical analysis showed that the gained water is found to be almost distilled water with a $\mathrm{pH}$ of approximately 7 , in addition to the presence of a group of chemical elements and ions.

- The physical test revealed that the water characterizes with low turbidity, very low electrical conductivity, within the range of $25 \mu \mathrm{S} / \mathrm{cm}-46 \mu \mathrm{S} / \mathrm{cm}$, and very low TDS.
- The water gained from this system can be used in the electrolysis cells for hydrogen gas production at a low cost as this pure water is a byproduct of the cooling airconditioning units.

- It is proved that the solar disinfection technique is very effective to inactivate $99.9 \%$ of the present bacteria in the tested water, with an irradiation exposure time of about 2.5 h during sunny weather.

- The solar disinfection technique is recommended to be used as an easy way for disinfecting the water that is subjected to be drinking water in places where approved disinfection methods are not available.

Acknowledgements. The authors would like to thank the Public Authority for Water, Al-Buraimi Province, Sultanate of Oman for very kind help and support to use their facilities for physical, chemical, and bacteriology tests of this research work. The authors greatly appreciate Dr. Ali Al-Hassnawi of the Oman Academic Accreditation Authority, Quality Assurance Consultant, for helpful proofreading. Also, the authors would like to thank Eng. Mubarak Al- Affari, and Eng. Nebras Alattar for great help to collect drain-water from the ACs in their houses in Muscat and Sohar.

\section{References}

1. M. Rachael, IWMI project report, Groundwater use and policies in Oman, September 2016, No. 14

2. O.R. Aziz, Oman water resources challenges between the present and the future, Arab. J. Bus. Manag. (2015) https:// www.researchgate.net/publication/283347544

3. T. Al-Awadhi, M. Shawky, Spatial assessment of water quantity stress in sultanate of Oman provinces: a gis based analysis of water resources availability, J. Geogr. Inf. Syst. 7, 565-578 (2015)

4. R. Bahar, M. Nurul Alam Hawlader, Desalination: conversion of seawater to freshwater, in 2nd International Conference on Mechanical, Automotive and Aerospace Engineering (ICMAAE 2013), 2-4 July 2013, Kuala Lumpur

5. G.F.L. Al-Doori, I.S. Moosa, A.A.M. Saleh, Enhanced productivity of double-slope solar still using local rocks, Int. J. Smart Grid Clean Energy 8, 307-312 (2019)

6. M.T. Chaichan, H.A. Kazem, Water solar distiller productivity enhancement using concentrating solar water heater and phase change material (PCM), Case Stud. Therm. Eng. 5, 151-159 (2015)

7. M.T. Chaichan, H.A. Kazem, Using aluminum powder with PCM (Paraffin Wax) to enhance single slope solar water distiller productivity in Baghdad - Iraq winter weathers, Int. J. Renew. Energy Res. 5, 251-257 (2015)

8. T.M. Chaichan, K.I. Abaas, H.A. Kazem, Design and assessment of solar concentrator distillating system using phase change materials (PCM) suitable for desertic weathers, Desalination and Water Treatment 57, no. 32, 14897-14907 (2016)

9. M.T. Chaichan, H.A. Kazem, Single slope solar distillator productivity improvement using phase change material and $\mathrm{Al}_{2} \mathrm{O}_{3}$ nanoparticle, Solar Energy 164, 370-381 (2018)

10. O.A.H. AL-Musawi, A.A. Khadom, H.B. Manhood, M.S Mahdi, Solar pond as a low grade energy source for water desalination and power generation: a short review, Renew. Energy Environ. Sustain. 5, 4 (2020) 
11. S.H. Al Shibli, Sultanate of Oman's strategy for securing water resources, in The 11th Gulf Water Conference in GCC, Water in GCC Toward Efficient, 2014, https://wstagcc.org/ WSTA-11th-Gulf-Water-Conference/Oman-Water_Resour ces_Strategy.pdf

12. I.S. Moosa, B.B. Maqableh, N. Alattar, Production of fresh water from drain-water released from cooling air-conditioning systems: experimental and analysis studies, Int. J. Comput. Appl. Sci. 5, 350-355 (2018)

13. J.D. Burch, K.E. Thomas, Water disinfection for developing countries and potential for solar thermal pasteurization, Solar Energy 64, 87-97 (1998)

14. W. Gao, UV-B radiation: definition and characteristics, Professor Ecosystem Science and Sustainability Department. Director, USDA UV-B Monitoring Program Natural Resource Ecology Laboratory Colorado State University. Available at https://uvb.nrel.colostate.edu/UVB/publica tions/UV-Primer.pdf

15. G.M. Ayoub, L. Malaeb, Solar water disinfection: UV radiation transmittance of various solar reactor tubes, Energy Proc. 157, 498-511 (2019) https://doi.org/ 10.1016/j.egypro.2018.11.214

16. WHO/SDE/WSH/03.04/45, Chlorine in Drinking-water, Background document for development of WHO Guidelines for Drinking-water Quality, World Health Organization 2003, https://www.who.int/water_sanitation_health/dwq/ chlorine.pdf.

17. T. Arzu, Ç.E. Sevil, Drinking water disinfection by solar radiation, Environ. Ecol. Res. 5, 400-408 (2017)

18. E.H. Lacey, Exploring Pretreatments for the Solar Water Disinfection (SODIS) Process, Thesis, Waterloo, Ontario, Canada, 2008
19. M. Samrath, Solar Water Disinfection, Thesis, Arizona State University, 2011

20. R. Kumar Verma, S.C. Prasad, Solar Disinfection of Water (SODIS): an approach of last century improving till today, Conference Paper March 2013, Hazardous waste management and healthcare in India, At IEI, Patna, Available at https://www.researchgate.net/publication/ 275638098

21. B. Dawney, J.M. Pearce, Optimizing the solar water disinfection (SODIS) method by decreasing turbidity with $\mathrm{NaCl}$, J. Water Sanitat. Hygiene Dev. 2, 87-94 (2012)

22. I.S. Moosa, B.B. Maqableh, Temperature Difference with respect to exposure time for black paint and Galena powderback paint composite selective surfaces, in Transition toward $100 \%$ renewable energy, edited by A. Sayigh (Springer International Publishing AG, 2018), Chap. 13, pp. 137-147

23. G.R. Nabi Bidhendi, H. Hoveidi, H.R. Jafari, A.R. Karbassi, T. Nasrabadi, Application of ozonation in drinking water disinfection based on an environmental management strategy approach using SWOT method, Iran. J. Environ. Health. Sci. Eng. 3, 23-30 (2006)

24. Swiss Federal Institute of Environmental Science and Technology (EAWAG), Department of Water and Sanitation in Developing Countries (SANDEC), Solar water disinfection, a guide for the application of SODIS, October 2002, ISBN Nr.: 3-906484-24-6, SANDEC Report No $06 / 02$

25. J.M. Ogden, Prospects for Hydrogen in the Future Energy System, Report, Institute of Transportation Studies, University of California, 2018, pp. 1-30 https://escholarship. org/uc/item/52s28641

Cite this article as: Iessa Sabbe Moosa, Laila Masoud Rashid Al-Iessi, Hussein A. Kazem, Freshwater production and solar disinfection of water released from the air-conditioning cooling system: an experimental investigation, Renew. Energy Environ. Sustain. 5, 9 (2020) 